\title{
FAKTOR VIRULEN STREPTOCOCUS MUTANS PENYEBAB TIMBULNYA KARIES GIGI
}

\author{
Febrian \\ Departemen of Dental Public Health Faculty of Dentistry Andalas University
}

\section{PENDAHULUAN}

Karies yang disebut juga sebagai lobang gigi merupakan penyakit jaringan keras gigi yang sudah ada sejak zaman dulu, baru tahun 1890 secara ilmiah WD Miller menyatakan bahwa timbulnya karies sebagai akibat interaksi kumankuman pathogen yang ada pada rongga mulut dan pada tahun 1914 Black menyatakan bahwa peristiwa terjadinya karies digambarkan sebagai akibat aksi asam organik dari kuman terhadap kalsium fosfat gigi. ${ }^{1}$

Penanganan karies awal mulanya lebih bersifat kuratif, ini dibuktikan adanya catatan arkeologi bangsa Yunani 1250 sebelum masehi yang melakukan pencabutan atas penangangan lobang gigi, penanganan karies ini berkembang dengan di lakukannya penambalan lobang gigi dengan bahan sejenis perak oleh Rhazes (Arab) 900 M, penambalan dengan emas $1450 \mathrm{M}$ dan penambalan dengan amalgam 1833 M. Penanganan karies secara preventive di mulai tahun 1945 dengan melakukan fluoridasi air minum dan penambahan fluor pada pasta gigi pada tahun $1950 .^{1}$

Berdasarkan data WHO dari tahun 1980 sampai tahun 1998 rata rata angka Decay Missing Filling Teeth (DMFT) pada anak usia rata rata 12 tahun di negara negara maju Amerika dan Eropa terjadi trend penurunan, sebaliknya untuk negara berkembang di Asia dan Afrika angka DMFT terjadi trend peningkatan. Di sebagian besar negara-negara berkembang, hal ini disebabkan oleh meningkatnya konsumsi gula dan kurang memadai paparan fluor pada gigi sebaliknya negara maju mereka telah memiliki program program yang bersifat preventif yaitu penggunaan fluor secara indifidu dan masal serta mereka telah berusaha mengubah gaya hidup sehat. Rata rata angka DMFT secara global untuk semua negara berkisar 2 dan 3 namun Indonesia 
berdasarkan laporan Riset kesehatan dasar angka DMFT masih tetap tinggi yaitu $4,7 .^{2}$

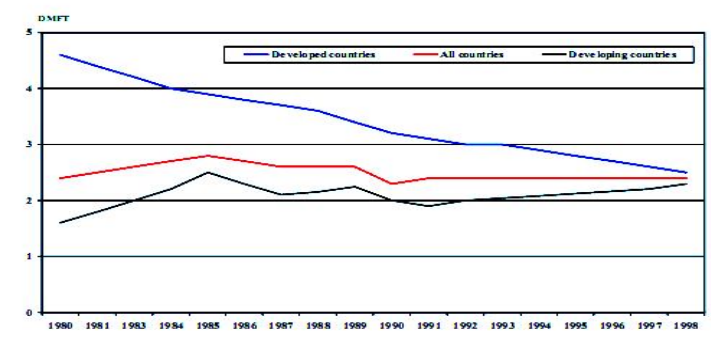

Gambar 1. Angka DMFT Kelompok Negara Di Dunia Dari Tahun $1980-1998^{2}$

Penelitian Namal tahun 2005 pada 30 negara ternyata angka DMFT pada usia $35-44$ tahun rata rata berkisar 8,3-20.8. Untuk beberapa negara maju angka ini termasuk tinggi seperti Australia 20,8, Belanda 17,4, Jepang 13,7, Amerika 13,3. Hal ini berarti walaupun upaya preventif pada beberapa negara maju sudah sangat baik namun untuk upaya mengontrol peningkatan prevalensi karies untuk jangka panjang masih belum menunjukkan hasil yang memadai. ${ }^{3}$

Karies menjadi awal dari rusaknya gigi secara permanen bahkan apabila penetrasi kuman masuk ke area yang lebih dalam lagi akan menyebabkan pulpitis dan periodontitis apikalis yang bisa berlanjut gigi menjadi abses dan nekrosis bahkan bisa menjadi fokal infeksi. Secara nyata dampak penyakit karies ini sangat banyak antara lain bisa menimbulkan rasa sakit, ketidak nyamanan (discomfort), fungtional Limitation, disability, handicap. ${ }^{1}$

Akibat langsung dari dampak ini adalah begitu banyaknya anak yang tidak bisa masuk sekolah akibat sakit gigi, begitu banyaknya anak anak tidak bisa mengikuti pelajaran dengan baik di sekolah, begitu banyaknya anak bisa tidur dengan nyenyak, begitu banyaknya anak yang menjadi sulit makan, hal ini secara tidak langsung akan mempengaruhi prestasi belajar anak dan bahkan pertumbuhan tubuh dan otak si anak. Hal yang sama juga terjadi pada orang dewasa yang menderita karies gigi, mereka menjadi malas bekerja dan berusaha, pekerjaan menjadi terganggu. Berdasarkan data persentase Year Live with Disability (YLD), penyakit gigi (karies, periodontitis dan kehilangan gigi) adalah $1,5 \%$ dan angka YLD penyakit gigi ini lebih tinggi dari pada beberapa penyakit yang secara umum banyak di derita oleh orang di dunia ini seperti Diabetes, diare, malaria dan $\mathrm{TBC}^{4}$

Dilihat sudut ekonomi, penyakit karies gigi telah menjadi disease burden. Disability akibat penyakit gigi secara ekonomi mengakibatkan orang kehilangan pendapatannya, kehilangan pekerjaan, kehilangan kesempatan, dan mereka juga mengeluarkan banyak biaya untuk mencari pengobatan. Berbagai negara didunia 
termasuk Indonesia telah memprogramkan bahwa penanggulangan secara preventive menjadi prioritas utama penangulangan penyakit gigi. Karena dianggap upaya ini mempunyai cost lebih rendah dari pada kurative dan berdampak lebih luas dan terbukti mampu menurunkan prevalensi karies pada usia muda.

Berdasarkan etiologi terjadinya karies, karies terjadi apabila ada interaksi antara kuman, makanan yang kariogenik, gigi sebagai host. Selama ini upaya preventive telah dilakukan terhadap ketiga faktor penyebab itu. Program promotive dilakukan kepada setiap individu bagaimana cara untuk menghindari terjadinya karies seperti menghindari makan kariogenik, menggosok gigi yang baik. Upaya preventive lain juga dilakukan dilakukan secara masal seperti fluoridasi air minum, pemakaian fasta gigi mengandung fluor. Upaya preventive secara indifidu yaitu melakukan pit and fissure sealent.

Secara global, upaya preventive diatas dianggap cukup mampu menurunkan prevalensi kejadian karies di usia muda namun belum mampu mengontrol meningkatnya prevalensi diusia selanjutnya. Penelitian untuk upaya pencegahan karies ini tidak ada habisnya dilakukan, banyak penelitian dilakukan untuk meningkatkan dan menjaga ketahanan host melalui upaya remineralisasi email, mencegah terjadinya karies dengan mengurangi jumlah koloni kuman, mencegah perlekatan kuman di permukaan gigi dan juga penelitian tentang mencari faktor virulen microorganisma yang menjadi penyebab terjadinya karies

Selama ini streptococcus merupakan microorganisma yang merupakan flora normal di dalam mulut, dengan mengetahui faktor virulen penyebab terjadinya karies ini diharapkan akan dapat menemukan pula vaksin anti karies yang mampu menurunkan prevalensi dan mencegah timbulnya penyakit itu kembali, padahal menurut Fejerskov et al, 2008, bahwa penelitian tentang immunisasi karies ini telah di mulai oleh Bowen pada tahun 1969. Namun sampai saat ini vaksin anti karies bagi manusia belum ada. ${ }^{1}$

\section{MEKANISME TERJADINYA KARIES GIGI}

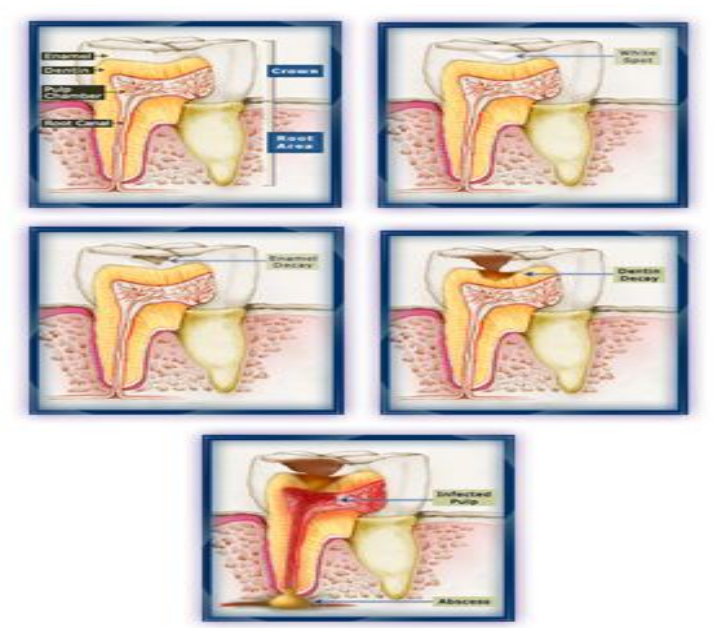


Gambar 2. Mekanisme Terjadinya Karies Gigi

Mekanisme terjadinya karies diawali oleh adanya bakteri penyebab karies yang terpapar oleh gula atau karbohidrat yang kariogenik dan kemudian bakteri ini akan menghasilkan asam. Produk asam ini akan berikatan substansi pada permukaan luar gigi sehingga menyebabkan terjadinya proses demineralisasi email. Tanda pertama proses ini adalah bercak putih yang disebut juga sebagai white spot. Demineralisasi berlanjut akan menyebabkan rusak dan hancur email gigi sehingga kemudian membentuk lobang gigi di permukaan email gigi. Keyes, 1960 menggambarkan bahwa ada 3 prasyarat terjadinya karies yaitu adanya plak, adanya diet karbohidrat dan gigi. ${ }^{5}$

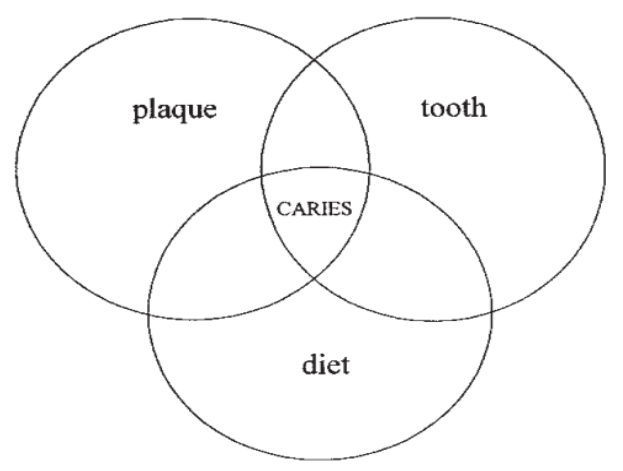

Gambar 3. Etiologi Terjadinya Karies Menurut Keyes ${ }^{1}$

Dengan berkembangnya ilmu pengetahuan terjadilah pergeseran paradigma bahwa tentang penanganan karies yang mana selama karies tidak bisa diicegah dan diperbaiki namun sekarang karies gigi diperlakukan sebagai penyakit menular yang dapat dicegah dan disembuhkan. Penangan ini berbeda dengan penanganan karies terdahulu yang hanya melakukan penanganan karies dengan pendekatan restorative. Ilmuwan Amerika menemukan metode Caries Managament By Risk Assessment (CAMBRA) yang merupakan pendekatan penanganan karies gigi dengan pendekatan pencegahan, mengembalikannya seperti keadaan semula dan mengobati karies gigi. Dengan menilai keseimbangan proses kejadian karies maka seorang klinisi dapat mencegah terjadinya karies. Keseimbangan karies dilihat dari faktor protektif yaitu saliva dan sealent, anti microba, fluoride, efektif diet dan faktor phatologik yaitu bacteria virulent, kurangnya flow saliva (xerostomia), habits poor diet. ${ }^{6}$

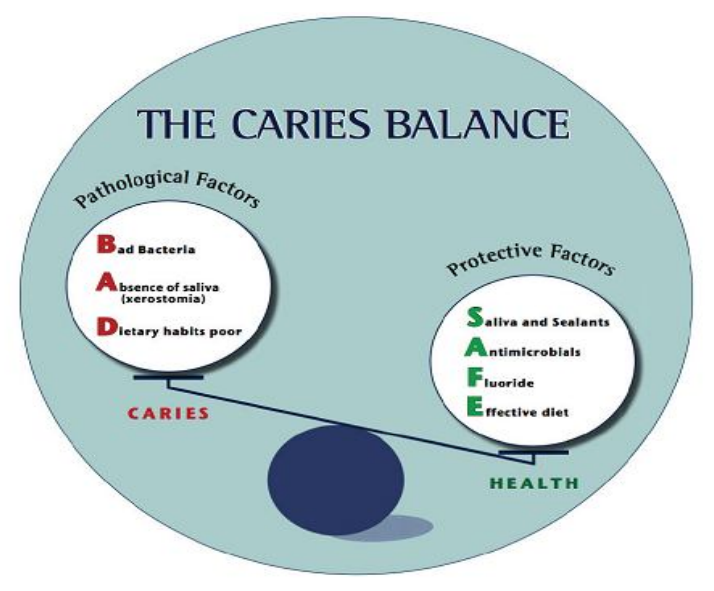


Gambar

4. Etiologi Terjadi Karies Berdasarkan Faktor Kesembangan Menurut Young ${ }^{6}$

Fejerskov et al tahun 2008 juga mengungkapkan ada 3 faktor penentu penyebab karies faktor pertama merupakan faktor utama yaitu permukaan gigi, jumlah koloni kuman dan PH. Faktor utama ini harus dijaga keseimbanganya oleh faktor kedua yaitu waktu, flow saliva, composisi saliva, fluor, komposisi dan frekwensi diet, spesies microorganisma, kemampuan bertahan (buffer capacity), makanan bebas gula (sugar clearence rate). Faktor ketiga adalah faktor pendukung yang digambarkan sebagai lingkaran terluar yang berpengaruh kepada terjadinya karies gigi yaitu tingkat pendidikan, klas sosial, pendapatan, kebiasaan, pengetahuan, sikap. ${ }^{1}$

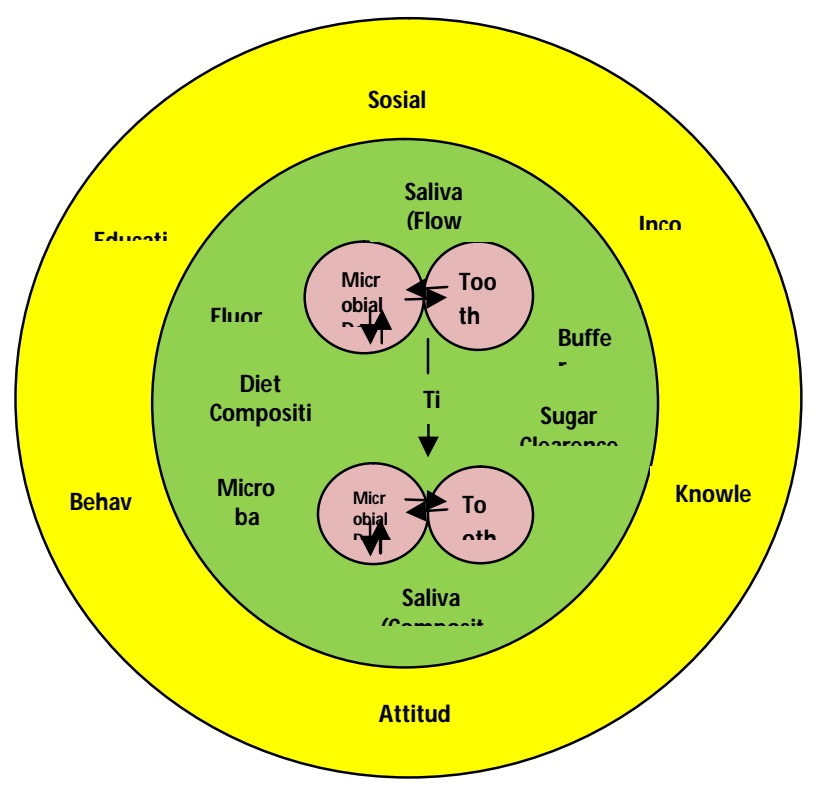

Gambar 5. Etiologi terjadinya karies menurut Fejerskov ${ }^{1}$

Meningkatnya deposit plak yang mengandung microorganisma virulen akan menyebabkan menurunkan $\mathrm{PH}$ pada permukaan gigi karena produk asam yang dihasilkan oleh microorganisma akan menyebabkan demineralisasi permukaan email gigi dan sebaliknya meningkatnya PH permukaan gigi dan berkurangnya jumlah microorganisma yang menempel pada permukaan gigi akan mencegah terjadinya karies gigi dan bahkan membantu proses remineralisasi dari permukaan gigi.

\section{ORGANISME PENYEBAB KARIES DAN PATOGENESIS KARIES}

Microorganisma merupakan penyebab terjadinya karies gigi ini sudah diketahui oleh Black, 1914 yang menyatakan bahwa karies gigi dimulai dari menempelnya kuman dipermukaan gigi kemudian kerkembang dalam jumlah yang banyak pada satu titik di permukaan gigi tersebut sehingga membentuk sebuah lobang yang makin lama makin membesar, namun lebih jauh sebelumnya Antonie Van Leewenhoek, 1674 telah mengetahui bahwa dalam rongga mulut terdapat banyak sekali microorganisma setelah ia menemukan microskop dan melakukan 
observasi terhadap plak gigi. Baru tahun 1960 Keyes dalam penelitiannya menjelaskan adanya kaitan antara microorganisma dengan diet karbohidrat dan permukaan gigi sebagai faktor penyebab dari timbulnya karies gigi. ${ }^{1,7}$

Dari berbagai penelitian tentang microorganisma diketahui bahwa rongga mulut merupakan sebuah ekosistem microorganisma yang memberikan lingkungan yang mendukung bagi perkembangan bakteri. Bebagai macam spesies microorganisma diketahui membuat ribuan koloni di rongga mulut. Penelitian tentang microorganisma di rongga mulut sangat menarik minat para ahli untuk menelitinya lebih mendalam lagi.

Bagg et al, 2006 dalam bukunya menyatakan bahwa dalam rongga mulut terdapat lebih kurang 350 spesies kuman yang berbeda dan dalam 1 mililiter saliva terdapat jutaan jumlah microorganisma namun hanya $50 \%$ dari jumlah spesies ini yang dapat di identifikasi dengan tehnik Kultur di laboratorium. Dengan ditemukan tehnik baru secara biomolekuler maka lebih banyak lagi jenis micro organisma yang bisa di identifikasi. ${ }^{7}$

Munson el al, 2003 melakukan identifikasi microorganisma yang terkait dengan karies gigi dengan menggunakan teknik kultur dan teknik identifikasi DNA dan ditemukan berbagai macam spesies microorganisma. Dengan kultur anaerob, microba dominannya adalah sp.proionibacterium (18\%), olsenella propusa (14\%), lactbacillus rhamnosus (8\%) dan dg Analisis Molecular microba dominannya adalah: streptococcus mutans (16\%), lactobacilus gasseri/jhonsonii (13\%), lactobacilus rhamnosus $(8 \%){ }^{8}$

Chhour et al, 2004 melakukan identifikasi microorganisme pada karies tingkat lanjut (karies dalam) dan ditemukan 75 spesies bakteri dan yang terbanyak adalah Jumlah microorganisma yang terbanyak adalah spesies laktobacilli $50 \%$, spesies prevotelae $15 \%$, Sisanya adalah dari spesies selenomonas, dialister, fusobacterium nukleatum, eubacterium, lachnospiraceae, olsenella, bifidobacterium, propionibacterium dan pseudoramibacter alactolycus. $^{9}$

Byun Roy et al, 2004 melakukan identifikasi terhadap spesies laktobacillus dan menemukan ada 9 macam gol spesies lactobacillus dan paling banyak adalah L.gasseri, L.ultunensis, L.Salivatorius, L.rhamnosos, L.casei, L.crispatus, L.delbrueckii. L.fermentum, L.gallinarum. ${ }^{10}$

Dari berbagai macam jenis spesies microorganisme yang terdapat didalam rongga mulut, yang berpotensi untuk menimbulkan karies adalah spesies bakteri 
yang mampu menempel pada permukaan gigi. Banyak penelitian yang menyebutkan tersebut adalah spesies streptococcus mutanss.

Grup streptococcus terdiri dari 7 spesies yaitu Streptococcus cricetus, S. Rattus, $\mathrm{S}$ mutanss, $\mathrm{S}$ sobrinus, $\mathrm{S}$ downei, $\mathrm{S}$ macacae, $\mathrm{S}$ ferus. Namun dilaporkan Streptococcus mutanss dan $\mathrm{S}$ sobrinus jumlahnya paling banyak terdapat dental plaque dan ada keterkaitannya dengan karies karena bersifat Acid Tolerant Response (ATR). Namun diantara keduanya streptococcus mutansslah yang paling dominan jumlahnya pada dental plak manusia. $^{11,12}$

Streptococcus mutanss adalah bakteri gram positif, nonmotil (tidak bergerak) dan anaerob fakultatif. Bakteri ini bersifat asidogenik (menghasilkan asam) dan asidurik (mampu hidup) di lingkungan asam. Untuk mendapatkan energinya bakteri ini membutuhkan fruktosa. Melalui metabolisme glikolisis fruktosa dirubah menjadi energi dan asam laktat dalam suasana anaerob. Asam laktat yang dihasilkan akan menuruhkan $\mathrm{PH}$ sehingga sampai dalam batas mampu menyebabkan demineralisasi email gigi. Bakteri ini juga mempunyai suatu enzim yang disebut glukosil transferase (Gtf) yang menyebabkan terjadinya polimerisasi glukosa yang membentuk suatu polisakarida yang lengket disebut dextran. Dextran pada beberapa artikel sering disebut dengan glucan. ${ }^{13}$

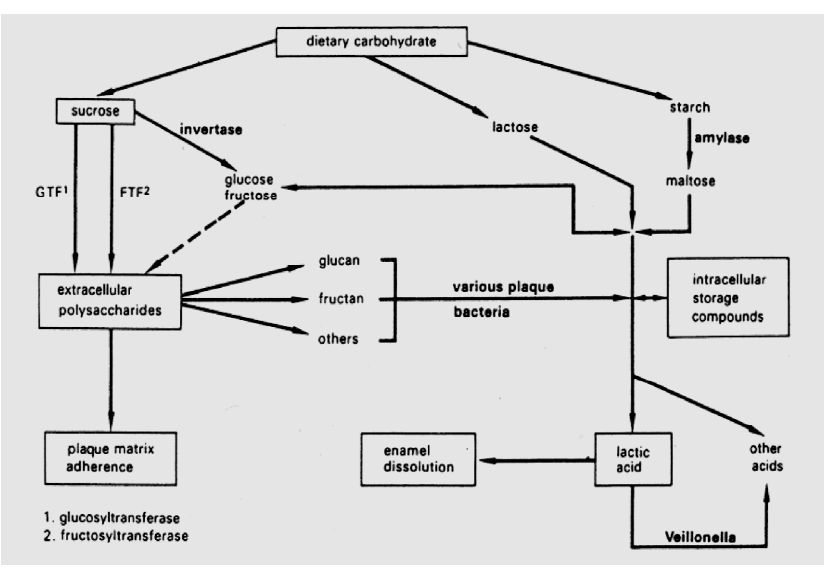

Gambar 6. Metabolisme Karbohydrat (www.dentistry.leeds.ac.uk : Oral Microbiologi)

Permukaan gigi selalu diselubungi oleh a celular protein film yang disebut juga dental biofilm. Dental biofilm ini dibentuk dari formasi pelikel yang merupakan glicoprotein saliva, phospoprotein dan lipid. Dengan adanya dextran, streptococcus mutanss menempel pada permukaan dental biofilm. Suasana asam dan lengket yang dibuat oleh streptococcus mutans pada permukaan dental biofilm ini menarik juga spesies bakteri lain yang bersifat acidurik sehingga membentuk koloni koloni diatas permukaan dental biofilm. Dental biofilm ini yang dipenuhi oleh microorganisma inilah yang disebut juga sebagai plak gigi. Walaupun begitu banyaknya microorganisma di permukaan dental 
biofilm namun hanya streptococcus mutanss yang mampu bertahan dalam glicoprotein. ${ }^{1}$

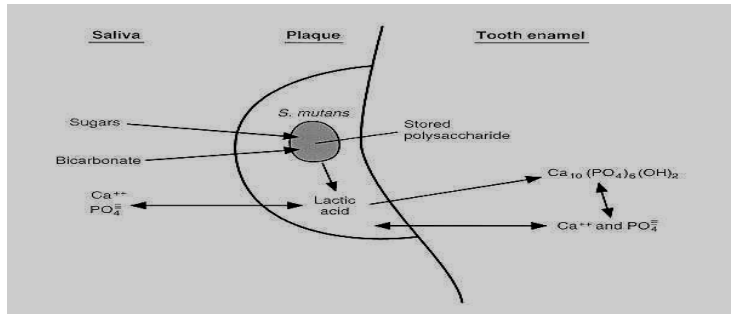

Gambar 7. Pathogenesis Of Dental Decay (http://www.ncbi.nlm.nih.gov: Medical Microbiologi)

Fishman, 2009 melakukan analisis biomolekuler microorganisma terhadap dental biofilm pada permukaan gigi yang mempunyai karies dan pada permukaan gigi yang berkaries, ternyata secara statistik tidak terdapat perbedaan yang bermakna jumlah spesies microorganisma pada biofilm permukaan gigi yang berkaries dan permukaan gigi tidak berkaries. ${ }^{14}$

Daya ikat (adhesi) membuat streptococcus menempel pada berbagai komponen permukaan tubuh manusia seperti kolagen, myosin, fibronectin dan laminin dan pada permukaan gigi dengan berbagai mineral dalam matrik email gigi dan juga berbagai komponen dari pelikel menutupi permukaan gigi seperti $\alpha$ amylase, proline rich protein, lysozome, saliva mucin dan parotid agglutinin glycoproten yang berasal dari saliva.
Untuk mengikat komponen diatas, streptococcus mutanss juga mempunyai komponen protein antigen permukaan yang disebut juga sebagai protein antigen I/II dan diketahui saat ini bahwa antigen ini berikatan dengan saliva agglutinin glycoproten. $^{15}$

Herdiyeti dan Satari, 2008 dalam penelitiannya mencoba membuktikan secara biologi molekuker apakah ada gen Gtf B dan Gtf C ada pada streptococcus mutanss, karena gen ini merupakan faktor virulen dari streptococcus mutans yang bertanggung jawab untuk sintesis glukan untuk menghasilkan polishakarida. ${ }^{16}$

Penelitian tentang dextran (glucan) oleh beberapa ahli ternyata menemukan glucan binding (pengikat glucan) yang merupakan protein receptor dari streptococcus mutans selain Gtf dalam mengikat glucan dan disebut juga sebagai Glucan binding protein (Gbp). Pada beberapa penelitian telah ditemukan berbagai macam protein Gbp yang dihasilkan oleh streptococcus mutanss. Gbp ini dikalsifikasikan kepada 4 macam Gbp yaitu Gbp A berfungsi sebagai biofilm morfologi, Gbp B berfungsi sebagai peptidaglycan Hidrolase, Gbp C berfungsi sebagai Aggregation, Gbp D berfungsi sebagai Cohesian/enzym. ${ }^{17}$ 


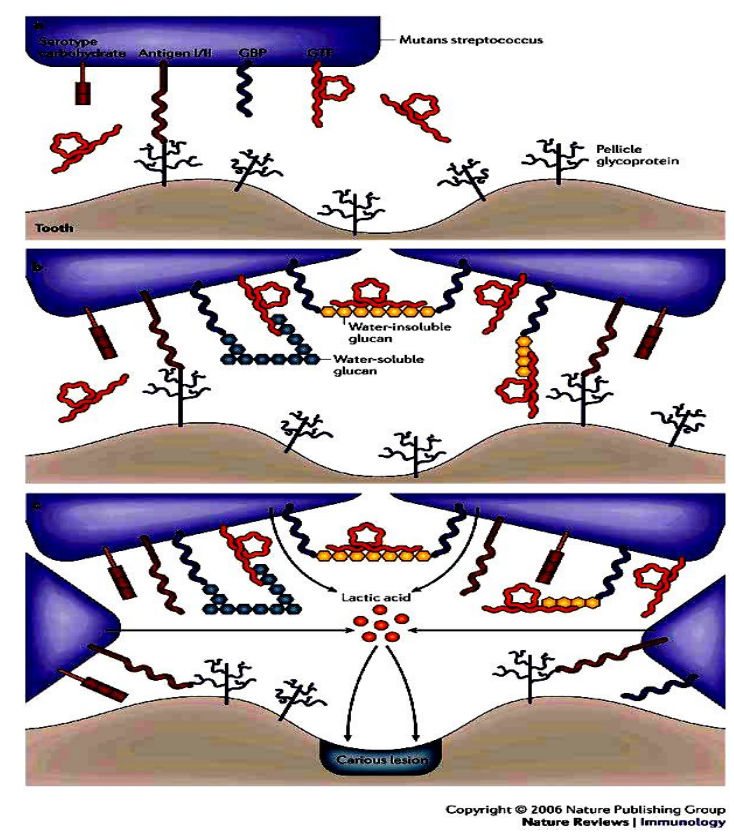

Gambar 8. The Molecular Pathogenesis Of Dental Caries Associated With Mutans Streptococci. ${ }^{18}$

\section{IMUN RESPON TERHADAP KUMAN}

\section{KARIES}

Rongga mulut adalah ekosistem yang baik bagi mikroorganisma karena rongga mulut menyediakan habitat yang menguntungkan. Sisa makanan dan rongga-rongga yang tersembunyi menjadi tempat berkembangnya mikroorganisma tersebut. Kondisi ini menjadi berbahaya apabila ekosistemnya berubah, mikroorganisma menjadi virulen mampu menembus mukosa bahkan jaringan keras gigi yang menghantarkan kuman untuk masuk kesistem sirkulasi.

Walaupun jumlah kuman yang ada dipermukaan mukosa rongga mulut dan permukaan gigi sangat banyak, namun rongga mulut mempunyai mekanisme pertahanan yang sangat kuat dan berlapis. Sistem pertahanan paling depan di rongga mulut adalah saliva. Saliva merupakan komponen yang penting dalam sistem pertahanan rongga mulut, selain memberikan efek self cleansing dalam membersihkan mikroorganisma pada permukaan mukosa mulut, gigi, gingiva dan lidah, saliva juga mempunyai komponen anti mikroba. Komponen itu antara lain $\operatorname{Ig}$ A, Lysozim, Peroxidase, Lactoferin dan leukosit. Ig A merupakan komponen yang sangat penting dalam mencegah menempelnya mikroorganisma pada permukaan mukosa mulut, gigi, gingiva dan lidah. Ig A dalam saliva diproduksi oleh sel plasma yang ada dalam kelenjar liur. ${ }^{7}$

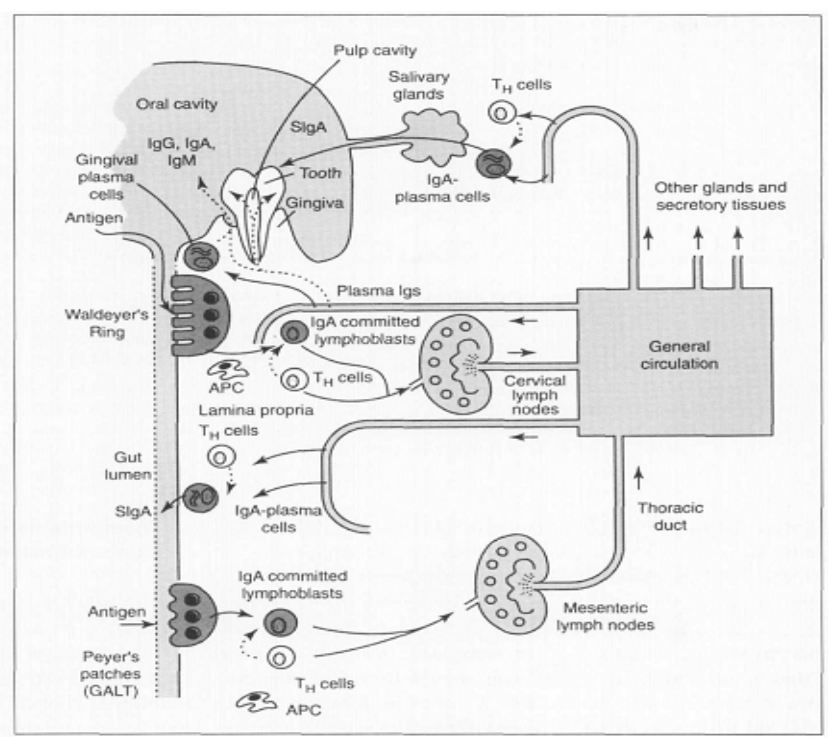

Gambar 9. Common Mucosal Immune System And Salivary Immunity $^{19}$ 
Beberapa penelitian menyebutkan respon imun tehadap antigen I/II streptococcus mutans dalam binatang percobaan banyak berinteraksi dengan Ig $\mathrm{G}$ atau berikatan dengan B cel epitop. Penelitian pada manusia menunjukkan adanya peningkatan jumlah B Cell epitop pada penderita endokarditis yang disebabkan oleh meningkatnya protein antigen I/II streptococcus mutans. ${ }^{15}$

Disamping menghambat terjadinya ikatan antara streptococcus mutanss dengan permukaan gigi, Ig A juga menghambat streptococcus mutanss untuk menghasikan asam dan menetralkan toxin dan mencegah antigen tersebut meresap melalui mucosa mulut namun Naspits, 1999 dalam penelitiannya menyebutkan tidak ada perbedaan level Ig A dengan perbedaan tingkatan karies pada gigi anak usia 3-5 tahun

Yuliani, 2008 mengindentifikasi epitop streptoococus terhadap antibody dan ternyata Peptida-peptida dari asam amino antigen I/II bereaksi terhadap Imunoglobulin A saliva baik pada permukaan gigi yang berkaries maupun yang bebas karies namun frekwensi antibodinya berbeda sangat signifikan dalam perhitungan statistik. ${ }^{20}$

Rashkova, 2009 mengidentifikasi jumlah imunoglobulin A pada anak yang memiliki dental karies dengan kondisi berbeda ternyata hasilnya perbedaan DMFT tidak mempunyai pengaruh yang signifikan jumlah sekresi imunoglobulin A Russel, 1999 menyatakan bahwa Ig A tidak ada waktu lahir, namun mulai berkembang minggu pertama postnatal hingga 6 bulan sehingga dalam jangka waktu itu Ig A disuplai dengan air susu ibu. oleh. Apabila ada bentuk imunisasi aktif terhadap streptococcus mutanss maka sangat efektif diberikan antara usia 6 bulan sampai 18 bulan. ${ }^{19}$

Antigen I/II, Gtf dan Gbp merupakan kelompok protein permukaan streptococcus mutanss. Pada beberapa penelitian, ketiga antigen ini merupakan faktor virulence dari streptococus mutans dan bisa menginduksi produksi sekresi Ig A dan Ig B. Kemampuan dalam menginduksi Imunoglobulin ini menjadikan ketiga faktor virulen ini menjadi strategis untuk membuat vaksin. ${ }^{21}$

Penelitian lain juga menyebutkan bahwa Ig A mampu menghambat sintesa sukrosa oleh streptococcus mutanss dan menekan kolonisasi streptococcus mutans di permukaan gigi. Pada experimen binatang percobaan, pemberian imunisasi terhadap mucosa mampu meningkatkan sekresi Ig A dalam saliva. ${ }^{22}$ 


\section{VAKSIN STREPTOCOCCUS}

\section{MUTANS}

Aspek pertahanan terhadap streptococus saat ini banyak diteliti oleh peneliti hal ini berkaitan dengan begitu tingginya minat peneliti untuk membuat vaksin anti karies gigi. Dengan mengetahui virurence faktor dari sebuah kuman akan dapat dibangun kandidat vaksin untuk mencegah penyakit. Dengan pendekatan biokimia ada 3 hal penting yang harus diketahui dari streptococcus mutanss sebagai penyebab penyakit yaitu sifat Aciduricity, Acidogenesis, sucrose dependent colonization. Dengan dasar biologi molekular sangat perlu dicari dan dimengerti faktor virulensi dari kuman penyebab penyakit mulut yang nantinya berguna sebagai pencegah terjadinya penyakit. Kemampuaan kecepatan kuman dalam mensintesa gula (sukrosa) menjadi asam laktat dapat dijadikan cara untuk mengungkapkan kuman streptococcus mutanss mana yang virulen, mana gen streptococcus mutans yang bersifat aciduricity. Sejumlah penelitian mencoba melihat gen strep mutans dari karakteristik ikatannya dengan permukaan gigi (adhesi) seperti Antigen I/II atau PAc. Sejumlag penelitian juga mencoba melihat gen dari kemampuannya mensintesa sukrosa seperti Glucotransferase (GtF) gen tersebut. ${ }^{23}$
Fan et al, 2002 melakukan uji klinis vaksin DNA pCIA-p terhadap sel protein antigen permukaan (PAc) yang pada beberapa artikel disebut sebagai antigen $\mathrm{B}$, atau antigen $\mathrm{P} 1$ atau antigen I/II. Uji coba pada binatang percobaan ternyata Vaksin DNA pCIA-p tidak mampu melindungi karies email yang mempunyai virulensi cariogenik yang kuat dan konsumsi sukrosa yang banyak pada makanan namun vaksin ini mampu memprovokasi respon imun spesifik. ${ }^{24}$

Guo et al, 2004 melakukan ujiklinis klinis binatang percobaan terhadap vaksin DNA pGLUA-P hasil mengkloning Glu Gtf pada Vaksin DNA pCIA-p. Vaksin ini merupakan fusi 2 vaksin karena streptococcus mutanss mempunyai 2 faktor virulens yaitu Glucosyltransferase (GTFs) dan Antigen Protein permukaan (PAc). Hasilnya menunjukkan pemberian DNA pGLUA-p memberi efek karies lebih sedikit dari pada jenis vaksin pCIA-p dan di simpulkan bahwa pemberian vaksin DNA multigenik lebih karie protektif dari pada single gen vaksin. $^{25}$

Weintraub et al, 2005 melakukan uji klinis pemberian antibody monoclonal (Guy'13 antibody) yang merupakan antibody yang secara langsung dapat menghambat daya ikat streptococcus mutanss pada permukaan gigi. Antibody 
ini melawan daya adhesi antigen I/II untuk melekat ke permukaan pelicle glicoprotein yang ada pada permukaan gigi. Namun sebelum pemberian antibody, sampel diberikan kumur chlorhexidine (CHX) yang mampu menghilangkan streptococcus mutans di rongga mulut. Hasilnya ternyata pemberian $\mathrm{CHX}$ mampu mengurangi jumlah streptococcus mutans pada rongga mulut namun pemberian antibody Guy'13 tidak mampu mempertahankan kondisi tersebut. $^{26}$

Xu et al, 2005 melakukan uji klinis untuk memastikan adanya efek Cytotoxic T Limfocyte Asoosiated Antigen 4 (CLTA 4) dalam menginduksi terbentuknya akselerasi serum Ig A dan Ig G. Dari beberapa antigen yang ada di ujikan dengan pemberiannya secara Intra muskular apakah mempunyai efek pada CLTA 4 dan ternyata pGLUA-P gagal menginduksi Ig A namun pGJA-P mampu meningkatkan imunitas sistemik mucosa dan di pastikan antigen pGJA-P bisa dijadikan vaksin anti karies. ${ }^{27}$

Xu et al, 2006 melakukan uji klinis terhadap daya tahan vaksin DNA pGJA/VAX sebagai booster imunisasi antikaries dalam tubuh. pGJA/VAX dibuat untuk mempercepat terbentuknya antibodi Ig A dan Ig $G$ dalam tubuh dengan mengkloning signal peptide dan extraselular region human cytotoxid $\mathrm{T}$ limfosit kedalam glucan binding gene streptococcus mutanss. Hasilnya adalah meningkatnya level Ig $\mathrm{G}$ setelah minggu ke 4 sesudah imunisasi sebanyak 3,4 $\mathrm{X}$, meningkatnya Ig A anti PAc di minggu ke 6 setelah imunisasi sebesar $15 \mathrm{X}$ diminggu dan meningkatnya Ig A anti Gtf di minggu ke 6 sesudah imunisasi sebesar $23 \mathrm{X}$ apabila dibandingkan dengan kontrol. $^{28}$

Zhang et al, 2007 melakukan uji klinis terhadap vaksin DNA CTLA 4 (Cytotoxic $\mathrm{T}$ Limfocyte Asoosiated Antigen 4) untuk mengevaluasi perbandingan imunogenitas dan efek protektifnya. Vaksin CLTA 4 adalah fusion DNA vaksin pGJA-P/VAX1, PGJA-P dan DNA pGLUA-P. Hasilnya vaksin DNA CTLA 4 lebih meningkatkan imunogenitas dibandingkan dengan vaksin yang lain. $^{29}$

Ada 2 faktor utama yang mengakibatkan strep mutans menjadi virulen yaitu adanya :Protein permukaan antigen (PAc) dan Glucotransferases (Gtf). Gtf mempunyai 2 fungsi utama yaitu sebagai $\mathrm{N}$ terminal Catalitic sucrosa binding (CAT) dan Sebagai C terminal glucan binding (GLU). Niu et al, 2009 mencoba mengclone catalitic fragmen (CAT) GTF streptococcus sobrinus memasukkannya kedalam vaksin pGJAP/VAX dan dilihat kemampuannya dalam 
menghambat sintesis water isoluble glucan. Hasil ini dapat dijadikan kandidat vaksin yaitu New recombinant plasmid pGJGAC/VAX. ${ }^{30}$

Walaupun secara preventif sudah banyak upaya yang dilakukan untuk mencegah karies namun bertambahnya populasi dan berkembangnya industrialisasi sebuah negara tidak mampu menahan prevalensi karies. Dengan dasar biologi molekular sangat perlu dicari dan dimengerti faktor virulensi dari kuman penyebab penyakit mulut yang nantinya berguna sebagai pencegah terjadinya penyakit.

Demikian juga dengan faktor transmisi, karena dengan mengetahui faktor transmisi dari suatu kuman kita dapat mencegah perpindahanya. Analisis biomolekuler yang pernah dilakukan Napimoga et al, 2004 ada sejumlah 52 genotipe streptococcus mutan yang ditemukan pada seorang anak balita, namun hanya 16 genotipenya yang sama dengan genotipe streptococcus mutans dari ibu, hal ini mengindentifikasikan selain ada transmisi vertikal antara keluarga ada juga transmisi horizontal yang harus diketahui. $^{21}$

\section{KESIMPULAN META ANALISIS}

Etiologi penyebab karies sangat banyak, mulai dari faktor yang menjadi penyebab langsung maupun faktor yang menjadi penyebab tidak langsung. Faktor penyebab tidak langsung berkaitan dengan pola hidup sehat. Faktor yang menjadi penyebab langsung dibagi atas faktor utama dan faktor pendukung. Faktor utama adalah microorganisma penyebab langsung yaitu streptococus mutans dan permukaan gigi sebagai host. Faktor pendukung adalah saliva, microorganisma diluar microorganisma penyebab utama, gula/sukrosa, waktu, frekwensi dan komposisi diet, keseimbangan asam basa, fluoride. Karies tidak akan terjadi apabila keseimbangan selalu terjaga antara faktor protektif anti karies dan faktor pathologis penyebab karies.

Penelitian banyak dilakukan untuk mencegah terjadinya karies. Penelitian yang berdampak langsung pada penurunan jumlah karies gigi adalah penelitian yang ditujukan kepada penyebab utama. Penelitian yang banyak dilakukan saat ini adalah mencari faktor virulen dari streptococcus mutan. Pencaharian vaktor virulen ini banyak digunakan dengan pendekatan imunologi dan biologi molekuler

Secara imunologi diketahui ada 3 penyebab utama yaitu adanya protein antigen permukaan dari kuman streptococcus mutans yang berikatan dengan permukaan gigi yang pertama adalah Antigen I/II atau disebut juga 
sebagai PAc, yang kedua adalah Glucosyltransferase atau disebut juga Gtf yang berfungsi sebagai enzym yang mensintesis sukrosa menjadi polishakarida yang bersifat lengket yang disebut juga sebagai glucan atau dextran. Yang ketiga adalah Glucan binding protein (Gbp) yang bekerja sebagai pengikat antar dextran/glucan. Sifat acidogenik dari streptococcus akan menghasilkan asam lactad yang menurunkan PH permukaan gigi sehingga membuat terjadinya demineralisasi dari matrik mineral permukaan gigi.

\section{Dengan ditemukannya faktor} virulen dari streptococcus mutans saat ini penelitian experimental banyak dilakukan untuk menemuan vaksin yang ampuh pencegah karies. Dengan perkembangan ilmu biomolekuler perlu diteliti lebih mendalam lagi tentang faktor virulen streptococcus mutans secara genom.

\section{KEPUSTAKAAN}

1. Fejerskov O, Kidd E. Dental Caries The Desease and Its Clinical Management. 2nd Edition. Blackwell Munksgaard. 2008.

2. World Health Organization. The World Oral Health Report 2003, Geneva, Switzerland. 2003.

3. Namal N, Vehid S, Sheiham A. Rangking Countries By Dental Status Using The DMFT And FS-T Indices, International Dental Jurnal. 2005; 85: 373-376.

4. Murray CJL, Lopez AD, Mathers CD, Stein C. The global burden of the disease. project: aims, methods and data sources, Global Programme on Evidence for Health Policy Discussion, Paper No. 36 World Health Organization (revised). 2001.

5. Decker Riva Touger, Loveran Cor van. Sugar and dental caries. America Journal Clinical Nutrition. 2003; 78:881S-92S.

6. Young DA, Buchanan PM, lubman RG, Badway NN. New Directions in Interorganizational Collaboration in Dentistry: The CAMBRA Coalition Model, Journal of Dental Education. 2007;71(5): 595-600.

7. Bagg J, Fariane MTW, Poxton IR, Smith AJ, Bagg S. Essential Of Microbiology For Dental Students. 2nd Edition. Oxford University Press. 2006.

8. Munson MA, Banerjee A, Watson TF, Wade WG. Molecular Analisys Of Microflora Associated With Dental Caries. Journal of Clinical Microbiology. 2004: 3023-3028.

9. Chhour K, Nadkarni M, Byun R, Martin FE, Jacques N, Hunter N. Molecular Analysis of Microbial Diversity In Advance Caries. Journal of Clinical Microbiology. 2004: 843-849.

10. Byun R, Nadkarni M, Chhour K, Martin FE, Jacques N, Hunter. Quantitative Analysis Of Diverse Lactobacillus Species Present In Advance Dental Caries. Journal of Clinical Microbiology. 2004: 3028-3036.

11. Igarashi T, Yamamoto A, Goto N. PCR For identification of Streptococcus Sobrinus. J Med Micro Biology. 2000: 49.

12. Nascimento MM, Lemos JAC, Abranches J, Gonchalver RB, Burne RA. Adaptive Acid Tolerance Response of Streptococcus Sobrinus. Journal of Bacteriologi. 2004; 186: 6383-6390.

13. Ryan KJ, Ray CG, Sherris. Medical Microbiology An Introduction to Infectious Diseases. 4ed. The McGraw-Hill Companies, Inc. 2004.

14. Fishman RH. The Molecular Analysis of The Biofilm of Proximal Incipient Caries In Young Permanen Teeth. Thesis Degree Master of Science The Graduate School of The Ohio State University. 2009.

15. Jenkinson Howard F. \& Demuth Donald R. Structure, function and immunogenicity of streptococcal antigen I/II polypeptides. Molecular Microbiology. 1997; 23: 183-190. 
16. Herdiyeti Y, Satari M H. Isolasi Gen Kariogenik Gtf BC Streptococcus Mutans Dari Plak Gigi Anak. Universitas Padjajaran Bandung. 2008,

17. Banas JA, Vickermann MM. Glucan Binding Protein of The Oral streptococcus. Critical Review Oral Biologi \& Medecine. 2003; 14: 89.

18. Taubman MA, Nash A. The scientific and public-health imperative for a vaccine against dental caries. Nature Reviews Immunology. 2006; 6: 555-563.

19. Russel MW, Hajishengalis G, Childers NK, Michalek SM. Secretory Immunity In Defense Against Cariogenic Mutans Streptococci. Caries Research. 1999; 33: 4-15.

20. Yuliani A. Identifikasi Epitop Dari Streptococcus Mutans terhadap Sekretori Imunoglobulin A Saliva, Universitas Airlangga Surabaya. 2008.

21. Napimoga MH, Hofling JF, Klen MI, Kamiya RU, Goncalves RB. Transmisssion Diversity And Virulence Factor Of Streptococcus Mutans Genotype. Journal of Oral Science. 2005; 47(2): 59-64.

22. Russel MW, Childers NK, Michalek SM, Suzanne M, Smith DJ, Taubman MA. A Caries Vaksin; The State Of Science of Immunization Again Dental Caries. Caries Research. 2004; 38: 230-235.

23. Kuramitsu HK. Virulence Properties of Oral Bacteria: Impact of Molecular Biology. Current issues Mol Biol. 2001; 3(2): 35-36.

24. Fan MW, Bian Z, Peng ZX, Zhong Y. DNA Vaccine Encoding A Cell Surface Protein Antigen Of Streptococcus Mutans Protects Gnotobiotic Rats From Caries. Journal of Dental Research. 2002; 81(11): 784.

25. Guo JH, Jia R, Fan MW, Bian Z. Construction And Immunogenik Characterization Of A Fusion Anti Caries DNA Vaccine Againts Pac And Glucosyltransferase I of Streptococcus Mutans. Journal of Dental Research.2004; 83(3): 266

26. Weintraub JA, Hilton JF, White JM, Hoover CL, Wycoff KL, YU L, Larrick JW, Featherstone JDB. Clinical Trial of Plant Derived Antibody On Recolonization of Mutans Streptococci. Caries Research. 2005; 39: 241250.
27. Xu Q, Yu F, Fan M, Bian Z, Guo J, Jia R, Chen $Z$, Peng B, Fan B. Imunogenicity And Protective Efficacy Of Targeted Fusion DNA Construct Against Dental Karies. 2005.

28. Xu Q, Yu M, Van MW, Bian Z. Immunogenicity And Persistence Of A Targeted Anti-Caries DNA Vaccine Journal of Dental Research. 2006; 85; 10: 915.

29. Zhang F, Li YH, Fan MW, Jia R, Xu QA, Guo JH, Tian QW. Enhanced Efficacy Of CTLA-4 Fusion Anti Caries DNA Vaccines In Gnotobiotik Hamsters. Acta Pharmacol Sin. 2007; 28(8): 1236-1242.

30. Niu Y, Sun J, Fan M, Xu QA, Guo J, Jia R, Li Y. Construction Of A New Fusion Anti Caries DNA Vaccine. Journal of Dental Research. 2009; 88(5): 455-460. 